\title{
CHANGING ROLE OF A TEACHER IN EDUCATIONALLY PROGRESSIVE MAHARASHTRA PROGRAMME
}

\author{
Patil Sandip Diliprao \\ RESEARCH SCHOLAR \\ Savitribai Phule Pune University, \\ Pune
}

Article DOI: https://doi.org/10.36713/epra5052

\begin{abstract}
This research paper discusses approaches and techniques which can assist teacher to improve their role in progressive education. It highlights use of new trends in teaching learning. Upon the practical study the paper diagnoses the drawbacks and limitations of current conventional teaching learning tools and methods. And suggests certain recommendations.
\end{abstract}

KEYWORDS- Classroom environment, Educational quality development, age appropriate learning abilities lifelong learning, Skills.

\section{INTRODUCTION}

Right to Education of Children's free and compulsory education came into existence and was implemented on $1^{\text {st }}$ April 2010 through out the state, which focused on quality education of children in age group 6 to 14 . Due to which there were some timely changes, these changes caused misunderstanding among the people such as bad effect on quality of education. It has been observed through survey that the achievement level of learners is different, diversified in different districts of the state. Hence there felt the need of supplementary guidance for those who were lagging in achievement level. Reading, writing numbers and operations etc, are very important to achieve the expected ability and to attain mastery. Keeping these things into consideration planned action programme had to be implemented of which "educationally progressive Maharashtra programme" resolution came into effect from June 2015. The programme focuses on helping teachers and educational quality development. So the implementation of this programme included gaining minimum expected learning abilities from all the regular students. No child should lag behind of these abilities. Hence the Government, administration, school management had to do effective trials but the main responsibility had to be shouldered by the teachers throughout the state. Hence taking into consideration all these things the researcher felt the need of identifying the pre- prejudiced state of teachers and new trends and ways given in the government resolution to cope with the needs for changing the role of teacher in educationally progressive Maharashtra Programme.

When we think of the classroom; teacher's roles and responsibilities, most likely planning instruction, delivering instruction, assessing student learning, and managing the classroom environment come to mind (Stronge, 2007). These are typical ways we know how to think about what a teacher does in and outside of the classroom. Hence various experiences and practices help teachers to develop themselves to be a facilitator for learners as it is said that the learner himself learns at his own speed and pace.

\section{NEED AND IMPORTANCE}

1) To give proper direction to learning of learner and the role of teacher as facilitator.

2) To know if the learner has gained expected abilities of age appropriate.

3) To attain mastery level by implementing action plan.

\section{METHODOLOGY}

\section{Method-Survey Method}

Sample- 30 teachers of Zilla Parishad schools from Nandurbar district selected randomly. 
Data collection tool-The Questionnaire was used. Statistical tool-The statistical tool Percentage was used.

\section{FINDINGS}

1) $95 \%$ teachers use traditional methods of teaching and learning.

2) $58 \%$ teachers use technology for their daily routines but not in learning teaching process.

3) $65 \%$ teachers need help from other teachers and experts for use of technology.

4) $92 \%$ teachers believe that using new tools, ways will help them learn faster than other ways to be a facilitator.

5) $83 \%$ teachers believe that using new technology ways will be effective for T-L process.

\section{CONCLUSIONS}

Thus, we visualize the aim of educationally progressive Maharashtra Programme therefore the role of a teacher is the development of knowledge, higher-order skills(such as the 4Cs of creativity, critical thinking, communication, collaboration), and character, as well as the establishment of lifelong learning habits and an ability to learn how-to-learn with technology as the central roles in the new picture of teacher effectiveness. New understandings about how children learn have informed reform efforts while at the same time challenging teachers to rethink their teaching practice. Teachers must have time and support to understand and accommodate these new visions with their experiences of practice. The reformation provides an opportunity, indeed the necessity, for teachers and others to re-examine and think deeply about teaching and learning in light of new research on learning and new perspectives on educational practice.

\section{SUGGESTIONS}

1) Teachers must design instruction that motivates each student by providing experiential, authentic, and challenging experiences.

2) Teachers must plan to be facilitators who provide scaffolding to support students in developing their own personal ways of knowledge and thoughts.

3) Implementation of various classroom strategies will also enhances student motivation and decreases discipline problems.

4) Teachers will become more sophisticated in their analysis of their own teaching practice and needs for new professional learning experiences.

\section{REFERENCES}

1. Government Resolution-EQD/2015/(80/15)S.D.6 dated 22/06/2015

2. Government Circular-EQD/2015/(80/15)S.D.6 dated 1708/2015

\section{Books}

1. Best John W. \& Kahn James V.:Research in Education,New Delhi:PHI Learning Private Limited.

\section{URLS cited-}

1. https://mscert.org.in/documents/Pragat_Shaiksha nik_Varta_English_Final_August_2016.pdf

2. http://timesofindia.indiatimes.com/homeleducatio n/news/Maharashtra-schools-to-focus-on-betterattendance-teachingskills/articleshow/49614161.cms

3. https://orfcaser.wordpress.com/2015/08/29/towar ds-an-educationally-progressive-maharashtral

4. http://www.p21.org/news-events/p21blog/1791 the-changing-roles-of-teachers-what-researchindicates-part-i-of-ii- 